\title{
sciendo
}

\section{Prevention of cardiovascular disease and eating behaviour in postmenopausal women}

\begin{abstract}
Introduction. A balanced diet can help to prevent cardiovascular diseases. It particularly applies to the increased risk patients, including postmenopausal women with dyslipidaemia.

Aim. The aim of this study was to assess dietary habits, and consumption of selected nutrients which may have influence on the cardiovascular risk and determine nutritional knowledge in the group of women.

Material and methods. The study was conducted in 60 postmenopausal women with dyslipidaemia. The nutritional status was assessed on the basis of anthropometric measurements. The assessment of nutrition was evaluated using a 24-hour dietary recall during 4 days. Based on the authors' questionnaire, dietary habits and the level of knowledge on the cardiovascular risk factors were assessed.

Results. The diet of the studied group of women was characterized by excessive supply of energy derived from fat and inappropriate supply of cholesterol, dietary fiber, sodium and vitamin D. Based on the assessed dietary habits, it was shown that the patients preferred foods with reduced fat content and mostly added salt for preparing their meals. Knowledge of factors affecting cardiovascular risk was insufficient.

Conclusions. Inadequate diet with insufficient nutritional knowledge in the studied group of women may significantly increase the risk of cardiovascular diseases in the future.
\end{abstract}

Keywords: cardiovascular disease, menopause, prevention, assessment of nutrition, dietary habits, dietary knowledge.

DOI: $10.2478 /$ pjph-2019-0004

\section{INTRODUCTION}

Cardiovascular disease is the major cause of death in the world, especially in postmenopausal women [1-3]. Additionally, diagnosing dyslipidaemia in these patients may significantly increase the cardiovascular risk [4]. Therefore, implementation of the prevention in menopause is extremely important [5].

As a result of heart disease prevention studies have shown an undeniable association between adherence to dietary recommendation and cardiovascular risk [6]. Furthermore, changes in dietary habits may cause significantly reduced risk of cardiovascular disease $[7,8]$.

In this research, participants were recruited using selected inclusion and exclusion criteria in order to reduce factors that may have influence on the studied parameters.
AIM
Estimating the eating behaviour, assessment of nutrition and knowledge of selected risk factors of cardiovascular dise- ase in postmenopausal women with dyslipidaemia.

\section{MATERIAL AND METHODS}

In this study, 450 aged women were recruited from the Wielkopolska Voivodeship. Subjects were included in the study only if they met all of the following criteria. The inclusion criteria in the study were: dyslipidaemia, natural menopause (absence of menstrual period for at least 12 months). Exclusion criteria were: diabetes, cancer, as well as liver, kidney, thyroid or heart disease, alcohol use more than $10 \mathrm{~g}$ ethanol per day, eating disorders or using any medical treatment. The target study was carried out among 60 postmenopausal women (aged 45-65 years).

The assessment of nutrition was evaluated using 24-h dietary recall method taken over 4 days ( 2 week days and weekend) according the Food and Nutrition Institute guidelines [9]. Each participant was trained by a dietician in order to properly complete the questionnaire. An album of food products was used to determine the amount of consumed foodstuffs [10]. The results were analysed using our own, previously created, computer database (Microsoft Access 10.0) prepared on the basis of tables for the composition and nutritional value of food products [11]. Daily intakes of selected nutrients, i.e. sodium, potassium, vitamin $\mathrm{D}$ and dietary fiber were referred to Polish adequate intake (AI), while magnesium was referred to the estimated average requirement (EAR) [12]. 
The nutritional status was carried out on the basis of anthropometric parameters studies [13]. The Body Mass Index (BMI) was calculated as weight/height squared $\left(\mathrm{kg} / \mathrm{m}^{2}\right)$.

Knowledge about prevention in cardiovascular disease was estimated using a dietary questionnaire. The questions included major cardiovascular risk factors and were developed on the basis of the European Society of Cardiology (ESC) recommendation. This study protocol was accepted by the Bioethics Committee at the Poznan University of Medical Sciences (Resolution No. 561/13 of June 13, 2013).

The statistical analysis was conducted using the statistical program StatSoft, Inc. (2016) Statistica (data analysis software system), version 13,1. Basic descriptive statistical methods were used, specifying: mean (x), standard deviation (SD), lower quartile (Q1), upper quartile (Q3).

\section{RESULTS}

The anthropometric characteristics of the studied women was presented in Table 1. Based on classification, the average BMI value in the study subject indicated the overweight. Additionally, it should be noted that in $25 \%$ women the BMI value was the same or higher than $29.2 \mathrm{~kg} / \mathrm{m}^{2}$ (overweight was observed in $30 \%$ of women, while obesity in $25 \%$ ).

The characteristics of the energy and selected nutrients were presented in Table 1. The estimate energy requirement in the studied group was slightly exceeded. The percentage of energy from protein, carbohydrates and simple sugars were consistent with recommended values. The analysis of the fat content in allday food rations showed discrepancies compared to the dietary

TABLE 1. Characteristics of study subject.

\begin{tabular}{|c|c|c|c|c|}
\hline Parameter & $\mathbf{M} \pm \mathbf{S D}$ & Q1 & Q3 & Norm \\
\hline Age [years] & $56 \pm 5$ & 53 & 59 & - \\
\hline Body weight $[\mathrm{kg}]$ & $70.7 \pm 15.9$ & 59.2 & 76.2 & - \\
\hline Height $[\mathrm{cm}]$ & $162 \pm 5$ & 160 & 166 & - \\
\hline BMI [kg/m2] & $26.8 \pm 5.8$ & 22.9 & 29.2 & $18.5 \leq \mathrm{BMI}<25$ \\
\hline Energy [kcal] & $2157 \pm 401$ & 1825 & 2367 & $2000-2100$ \\
\hline Protein [E \%] & $15.4 \pm 2.3$ & 14.0 & 16.7 & $10-20 \% \mathrm{E}$ \\
\hline Carbohydrates [E \%] & $49.2 \pm 6.1$ & 44.9 & 52.6 & $45-65 \% \mathrm{E}$ \\
\hline Simple sugars [E \%] & $9.1 \pm 3.3$ & 6.4 & 11.0 & $<10 \% \mathrm{E}$ \\
\hline Fat $[\mathrm{E} \%]$ & $39.1 \pm 5.3$ & 35.0 & 42.6 & $20-35 \% \mathrm{E}$ \\
\hline SFA [E \%] & $12.5 \pm 3.5$ & 9.6 & 14.7 & $<6 \% \mathrm{E}$ \\
\hline MUFA [E \%] & $15.5 \pm 2.6$ & 13.6 & 17.4 & - \\
\hline PUFA [E \%] & $7.6 \pm 2.8$ & 5.9 & 9.0 & - \\
\hline EPA [E \%] & $7.4 \pm 2.7$ & 5.8 & 8.4 & - \\
\hline EPA \& DHA [mg] & $440 \pm 596$ & 60 & 600 & $250 \mathrm{mg} / \mathrm{d}$ \\
\hline ALA [E \%] & $1.3 \pm 0.6$ & 1.0 & 1.7 & $0,5 \% \mathrm{E}$ \\
\hline $\mathrm{LA}[\mathrm{E} \%]$ & $6.1 \pm 2.5$ & 4.5 & 7.1 & $4 \% \mathrm{E}$ \\
\hline Cholesterol [mg] & $461 \pm 219$ & 295 & 547 & $<200 \mathrm{mg}$ \\
\hline Dietary fiber $[\mathrm{g}]$ & $24 \pm 8$ & 20 & 27 & $25 \mathrm{~g}[\mathrm{AI}]$ \\
\hline Sodium [mg] & $2303 \pm 676$ & 1779 & 2862 & $1400 \mathrm{mg}[\mathrm{AI}] *$ \\
\hline Potassium [mg] & $3556 \pm 728$ & 3048 & 4041 & $3500 \mathrm{mg}$ [AI] \\
\hline Magnesium [mg] & $362 \pm 106$ & 286 & 412 & $265 \mathrm{mg}$ [EAR] \\
\hline Vitamin $\mathrm{D}[\mu \mathrm{g}]$ & $1.0 \pm 1.0$ & 0.4 & 1.3 & $15 \mu \mathrm{g}[\mathrm{AI}]$ \\
\hline
\end{tabular}

M - average; SD - standard deviation; Q1 - lower quartile; Q3 - upper quartile;

EAR - Estimated Average Requirement; AI - Adequate Intake

* women $<50$ years old $-1500 \mathrm{mg}$ guidelines. The percentage of energy from fat was exceeded (39\%). The percentage of energy from saturated fatty acids (SFA) was $12.5 \%$ and was significantly higher than the recommended values ( $<6 \%$ of energy). The percentage energy of unsaturated fatty acid was $15.5 \%$ for MUFA, $7.6 \%$ from PUFA and $7.4 \%$ from EPA. The consumption of EPA, DHA, $\alpha$-linolenic acid (ALA), linoleic acid (LA) was higher than recommended. The average consumption of dietary cholesterol exceeded the dyslipidaemia recommendations $(<200 \mathrm{mg} /$ day $)$. The content of dietary fiber in all-day food rations in studied women did not fulfill the dietary recommendations. The consumption of sodium was significantly exceeded, while the consumption of potassium and magnesium was adequate. The average vitamin D content in the studied groups was $1.0 \mu \mathrm{g}$ where adequate intake for these patients is $15 \mu \mathrm{g}$.

The selected dietary habits which may be related to higher risk of cardiovascular disease were presented in Figure 1. The analysis of dietary habits mainly related to the consumption of table salt and intake fats from different sources. Adding table salt to the dishes was declared by $62 \%$ patients. Women preferred products with reduced fat content: $40 \%$ of participates consumed milk with reduced fat content and $37 \%$ used $12 \%$ fat cream. Patients mainly chose butter for spreads $(65 \%)$ and vegetable oils for cooking (99\%).

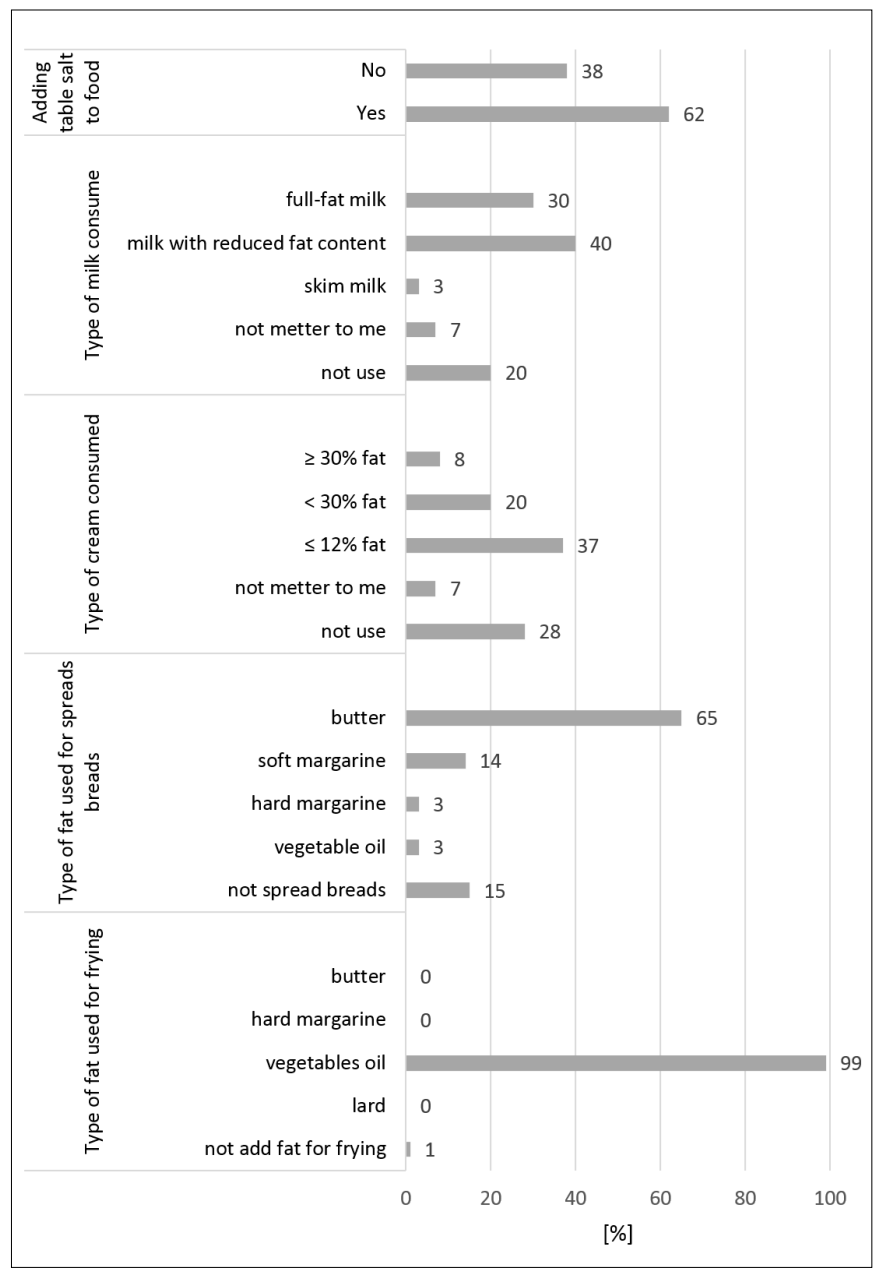

FIGURE 1. The selected dietary habits in studied group of women. 
TABLE 2. Knowledge of selected reducing risk factors of cardiovascular disease in women group - the percentage of total sample.

\begin{tabular}{lccc}
\hline \hline \multicolumn{1}{c}{ Factor } & Not known & $\begin{array}{c}\text { Known but } \\
\text { not applied }\end{array}$ & $\begin{array}{c}\text { Known } \\
\text { and applied }\end{array}$ \\
\hline Cessation or not taking up smoking & 18 & 13 & $69 *$ \\
\hline Regular exercises & $50^{*}$ & 43 & 7 \\
\hline Maintaining healthy weight & $48^{*}$ & 44 & 8 \\
\hline Reducing sodium intake & 25 & $45^{*}$ & 30 \\
\hline Reducing cholesterol intake & 37 & $47^{*}$ & 16 \\
\hline Reducing animal fat intake & 33 & $58^{*}$ & 9 \\
\hline Reducing sugar intake & 40 & $47^{*}$ & 13 \\
\hline
\end{tabular}

*the highest percentage

Knowledge regarding cardiovascular reducing risk factors was presented in Table 2.

There was a high percentage of women who do not know that both lack of regular exercises $(50 \%)$ and maintaining a healthy weight (48\%) belong to the cardiovascular risk factors. Other patients knew about these risk factors but claimed that they did not apply to them. With regard to other risk factors that women knew the risk but unfortunately did not apply in their lives: cessation or not taking up smoking (69\% women were aware of it although they did nothing about it), reducing sodium intake (45\%), reducing cholesterol intake (47\%), reducing animal fat intake (58\%), reducing sugar intake (47\%).

\section{DISCUSSION}

Occurrence of cardiovascular disease in postmenopausal women with dyslipidaemia is a common condition worldwide, including the Polish population. In connection with the above, conducting health prophylaxis regarding proper nutrition in menopause women is extremely important.

The diet of studied women was properly balanced under the energy value. The same result was observed in other studies about diet in postmenopausal women with dyslipidaemia $[14,15]$. It can be assumed that the occurrence of dyslipidaemia is not directly related to the excess energy in all-day food rations, but rather to the components of energy [16]. With regard to the nutrients of all-day food rations, the studied women's diets were improperly balanced. What is more, protein, carbohydrates and simple sugars intake in the group of women were correct. However, the fat intake was extremely higher that the recommended values. According to the ESC dietary guidelines, to reduce the risk of heart disease in patient with dyslipidaemia, reduction of intake of SFA in the diet is the most important [4]. Data analysis of all-day food rations showed that consumption of SFA by women was too high. What is more, these fatty acids are mostly delivered from rich in fat sweet snacks and from fat used for spreading bread. Additionally, it should be noted that day food rations were also rich in MUFA and PUFA; delivered from vegetable oils using to fry and fats added as raw ingredients to salads. Therefore, in these women it is not so important to increase the intake of unsaturated fatty acids (especially the consumption of EPA and DHA was also sufficient), but to reduce the intake of SFA which will contribute to reducing the total fat intake. Furthermore, disturbing fact was excessive (twice as high as the recommended) consumption of dietary cholesterol and insufficient intake of dietary fibre.
In the cardiovascular disease and dyslipidaemia diet, attention is paid to macronutrients i.e. sodium, calcium and magnesium. These mineral components have an influence on cardiovascular risk mainly through the interaction with blood pressure [17]. According the literature, the reduction of a daily sodium intake by $1 \mathrm{~g}$ decreases systolic blood pressure by $3.1 \mathrm{~mm} \mathrm{Hg}$ in hypertension patients and $1.6 \mathrm{~mm} \mathrm{Hg}$ in patients with normal blood pressure [18]. Moreover, increase in sodium consumption of $10 \mathrm{mmol}$ per day $(240 \mathrm{mg})$ contributes to a $1 \%$ increase of the cardiovascular risk [19]. In the studied subjects, the sodium intake exceeded the recommended values. Furthermore, it should be noted that in our studies we did not include adding table salt to the dishes.

It is widely known that the vitamin D pays an important role in the prevention of cardiovascular diseases [20]. The consumption of this vitamin by the studied women was insufficient. However, the main source of vitamin D is the skin synthesis (80\%) [20]. In connection with the above, the serum vitamin concentration should be controlled in postmenopausal women and, if it is necessary, supplementation should be recommended (especially in autumn and winter, where exposure to solar radiation is reduced).

As predicted, the analysis of dietary habits confirmed the increased consumption of table salt by the studied women. Most of them declared the addition of table salt to the dishes every day. This habit may increase the risk of hypertension. On the other hand, women preferred the products with reduced fat content. Unfortunately, they did not observe the fat content in all-day food rations. The high SFA intake in this study group may be associated with high butter consumption. The patients declared that the main fat for spreading bread was butter. Data analysis of the results showed that women consumed around $20 \mathrm{~g}$ butter a day, which was $10 \mathrm{~g}$ SFA.

In our study the patient's knowledge about the risk of cardiovascular disease was estimated. Excluding body weight and physical activity factors, most of the studied parameters was well known by women. Despite a lot of conducted preventiveepidemiological programs (including POLKARD, WOBASZ, NATPOL) not undertaking physical activity or unconsciousness of their need is a frequent observation. According to previously conducted study of dietary habits in cardiovascular disease on young people (20-30 years), women's inactivity is a frequent occurrence [21].

Awareness of reducing sodium intake is significantly related to sodium intake in all-day food rations, thus, increase the risk of cardiovascular diseases in the future. Insufficient knowledge of unfavourable influence of increased intake of dietary cholesterol and animal fats has been reflected in content of cholesterol and SFA in all-day food rations. The study emphasizes the importance of conducting preventive programmes, which will increase patients health awareness.

\section{CONCLUSIONS}

1. The awareness of negative effect of increased consumption of SFA, dietary cholesterol and reduced consumption of dietary fiber was sufficient in studied women. However, it should be noted that the study group did not follow the guidelines in their daily diet, which may significantly increase the cardiovascular risk in the future. 
2. The knowledge about preventive factors such as regular exercises and maintaining healthy weight was unknown. Therefore, pro-healthy activities in this area should be taken.

3. Particular attention in nutritional prevention should be paid not only to the knowledge of dietary recommendations itself, but also application of these recommendations in everyday life.

\section{CONFLICT INTEREST}

We declare that there is no conflict of interests which could have influenced impartiality and reliability of the paper entitled.

\section{REFERENCES}

1. Nichols M, Townsend N, Scarborough P, et al. European cardiovascular disease statistics 2012 edition. Sophia Antipolis: European Heart Network; 2012.

2. Cierniak-Piotrowska M, Marciniak G, Stańczak J. Statystyka zgonów i umieralności z powodu chorób układu krążenia. In: Z. Strzelecki, J. Szymborski (ed). Zachorowalność i umieralność na choroby układu krążenia a sytuacja demograficzna Polski. Warszawa: Rządowa Rada Ludnościowa; 2015.

3. Piskorz A, Brzostek T, Piórecka B. Występowanie wybranych czynników ryzyka chorób układu krążenia w grupie kobiet w okresie przedi pomenopauzalnym - analiza porównawcza. Hygeia Public Health. 2015;50(1):127-35.

4. Reiner Ž, Catapano AL, Backer G, et al. Wytyczne ESC/EAS dotyczące postępowania w dyslipidemiach. Kardiol Pol. 2011;69(4):144-99.

5. He L, Tang X, Hu YH. Relationship of menopause with cardiovascular disease and related metabolic disorders. Beijing Da Xue Xue Bao. 2016;48(3):448-53.

6. Perk J, De Backer G, Gohlke H, et al. Wytyczne ESC dotyczące prewencji chorób układu sercowo-naczyniowego w praktyce klinicznej w 2016 roku. Kardiol Pol. 2016;74(9):821-936.
7. Goh LG, Chua T, Kang V, et al. Ministry of health clinical practice guidelines: screening of cardiovascular disease and risk factors. Singapore Med J. 2011;52(3):220-5.

8. Ventura DA, Fonseca VM, Ramos EG, et al. Association between quality of the diet and cardiometabolic risk factors in postmenopausal women. Nutr J. 2014;13(1):1-10.

9. Charzewska J. Instrukcja przeprowadzania wywiadu o spożyciu z 24 godzin. Warszawa: Instytut Żywności i Żywienia; 1998.

10. Szponar L, Wolnicka K, Rychlik E. Album fotografii produktów i potraw. Warszawa: Instytut Żywności i Żywienia; 2000.

11. Kunachowicz H, Nadolna I, Przygoda B, et al. Tabele składu i wartości odżywczej żywności. Warszawa: PZWL; 2005.

12. Jarosz M. Normy żywienia dla populacji Polski. Warszawa: Instytut Żywności i Żywienia; 2017.

13. World Health Organization (WHO). Diet, nutrition and the prevention of chronic diseases. In: WHO technical report series 916, Geneva; 2003.

14. Waśkiewicz A, Sygnowska E, Jasiński B, et al. Wartość energetyczna i odżywcza diety dorosłych mieszkańców Polski. Wyniki programu WOBASZ. Kardiol Pol. 2005;63(6):1-7.

15. Grygiel-Górniak B, Przysławski J, Stelmach-Mardas M, et al. Sposób żywienia a insulinooporność $w$ grupie kobiet otyłych po menopauzie z dyslipidemii. Bromat Chem Toksykol. 2011;44(3):277-83.

16. Skop-Lewandowska A, Gąsior A, Zając J, et al. Ocena podaży energii oraz wybranych składników pokarmowych w całodziennych racjach pokarmowych kobiet z nadwagą i otyłością. Probl Hig Epidemiol. 2014;95(4):975-80.

17. Houston MC, Harper KJ. Potassium, magnesium, and calcium: their role in both the cause and treatment of hypertension. J Clin Hypertens. 2008;10(7):3-11.

18. He FJ, Li J, MacGregor GA. Effect of modest salt reduction on blood pressure: a meta-analysis of randomized trials. Implications for public health. J Hum Hypertens. 2002;16(11):761-70.

19. Poggio R, Gutierrez L, Matta MG, et al. Daily sodium consumption and CVD mortality in the general population: systematic review and metaanalysis of prospective studies. Public Health Nutr. 2015;18(4):695-704.

20. Gepner A, Ramamurthy R, Krueger DC, et al. A prospective randomized controlled trial of the effects of vitamin $\mathrm{D}$ supplementation on cardiovascular disease risk. PLoS One. 2012;7(5):e36617.

21. Dobrzyńska M, Przysławski J. Prevention of cardiovascular disease and eating behaviour in group of women and men aged 20 to 30 years. JMS. 2014;2(83):116-21.

\section{Corresponding author}

Dr Małgorzata Dobrzyńska

Department of Bromatology, Poznań University of Medical Sciences,

42 Marcelinska St., 60-354 Poznań

E-mail: mdobrzynska@ump.edu.pl

tel: +48618547198 